\title{
Ultrafast Electron Injection Dynamics of Photoanodes for Water-Splitting Dye-Sensitized Photoelectrochemical Cells
}

John R. Swierk, ${ }^{\dagger, 1}$ Nicholas S. McCool, ${ }^{\dagger, 2}$ Coleen T. Nemes, ${ }^{1}$ Thomas E. Mallouk, ${ }^{2-4, *}$ Charles A. Schmuttenmaer, ${ }^{, 1, *}$

${ }^{1}$ Department of Chemistry and Energy Sciences Institute, Yale University, 225 Prospect Street, P.O. Box 208107, New Haven, Connecticut 06520-8107, United States

${ }^{2}$ Department of Chemistry, ${ }^{3}$ Department of Biochemistry and Molecular Biology, and ${ }^{4}$ Department of Physics, The Pennsylvania State University, University Park, Pennsylvania 16802, United State
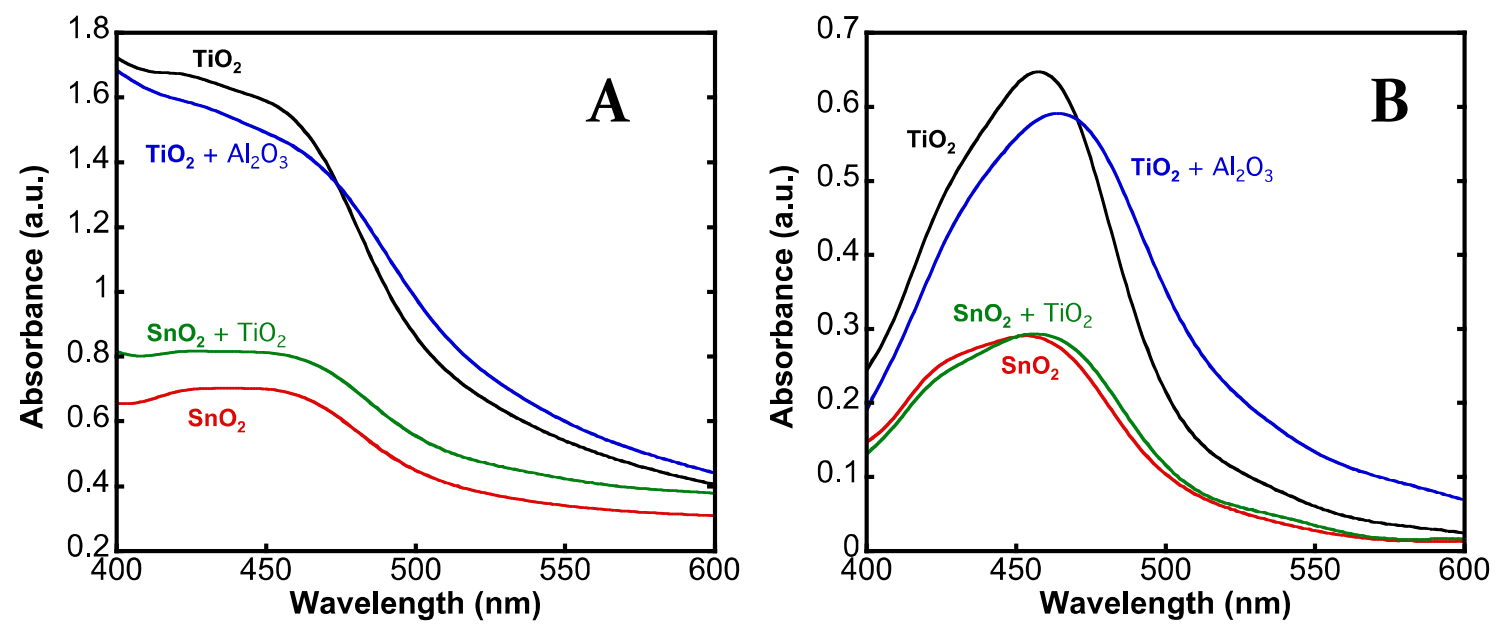

Figure S1: Raw (A) and scatter-corrected (B) steady-state UV-Vis spectra of sensitized films: $\mathrm{TiO}_{2}$ $\left[\mathrm{Ru}(\mathrm{II})\right.$ phos- $\left.\mathrm{TiO}_{2}\right], \mathrm{TiO}_{2}+\mathrm{Al}_{2} \mathrm{O}_{3}\left[\mathrm{Al}_{2} \mathrm{O}_{3}-\mathrm{Ru}(\mathrm{II})\right.$ phos-TiO $\left.{ }_{2}\right], \mathrm{SnO}_{2}\left[\mathrm{Ru}(\mathrm{II})\right.$ phos- $\left.\mathrm{SnO}_{2}\right]$, and $\mathrm{SnO}_{2}+\mathrm{TiO}_{2}$ $\left[\mathrm{Ru}(\mathrm{II})\right.$ phos- $\left.-\mathrm{SnO}_{2} / \mathrm{TiO}_{2}\right]$. Spectra corrected for scattering by subtracting the spectra of the unsensitized films. 